\title{
Health behaviors of people with hypertension: health belief model
}

\author{
Comportamentos de saúde de pessoas hipertensas: modelo de crenças em saúde
}

Conductas de salud de personas hipertensas: modelo de creencias en salud

Ariane Alves Barros ${ }^{1}$, Maria Vilaní Cavalcante Guedes ${ }^{1}$, Denizielle de Jesus Moreira Moura², Luciana Catunda Gomes de Menezes ${ }^{1}$, Letícia Lima Aguiar ${ }^{1}$, Gleudson Alves Xavier ${ }^{2}$

This study aimed to identify the lifestyle of hypertensive patients, focusing on their health behaviors in light of the Health Belief Model. This is a descriptive cross-sectional study with a sample of 133 patients over 18 years old, with hypertension, registered in the Clinical Management System for Hypertension and Diabetes Mellitus in Primary Care, and monitored in five health centers in Fortaleza, CE, Brazil, chosen randomly and probabilistically. Data collection happened through a structured interview that was designed based on the Health Belief Model, from March to December 2013. Participants perceived the disease's severity and felt susceptible to develop complications from hypertension. They reported receiving treatment correctly; however, the values of blood pressure, waist-hip ratio, and body mass index were high. Thus, it is necessary that health professionals implement strategies that favor hypertensive patients who are undergoing treatment to have healthy behavior.

Descriptors: Hypertension; Health Behavior; Nursing; Life Style.

Objetivou-se conhecer o estilo de vida de hipertensos, com enfoque nos seus comportamentos de saúde à luz do Modelo de Crenças em Saúde. Estudo transversal, descritivo, com amostra de 133 pacientes maiores de 18 anos, portadores de hipertensão arterial, cadastrados no Sistema de Gestão Clínica de Hipertensão Arterial e Diabetes Mellitus da Atenção Básica, e assistidos em cinco unidades de saúde de Fortaleza, CE, Brasil, escolhidas de forma aleatória e probabilística. Os dados foram coletados por meio de entrevista estruturada elaborada com base no Modelo de Crenças em Saúde, entre março a dezembro de 2013. Os participantes percebiam a severidade da doença e sentiam-se susceptíveis a desenvolver complicações advindas da hipertensão arterial. Afirmaram realizar o tratamento corretamente, no entanto, os valores da pressão arterial, relação cintura-quadril e índice de massa corporal encontravam-se elevados. Faz-se necessário que profissionais de saúde implementem estratégias que favoreçam comportamentos saudáveis de hipertensos em tratamento.

Descritores: Hipertensão; Comportamentos Saudáveis; Enfermagem; Estilo de Vida.

El objetivo fue conocer el estilo de vida de hipertensos, centrándose en sus conductas de salud a la luz del Modelo de Creencias en Salud. Estudio transversal, descriptivo, con 133 pacientes mayores de 18 años, registrados en Sistema de Gestión Clínica de Hipertensión y Diabetes Mellitus en Atención Primaria y asistidos en cinco centros de salud de Fortaleza, CE, Brasil, elegido en forma aleatoria y probabilística. Los datos fueron recolectados por medio de entrevista estructurada que se basa en el Modelo de Creencias en Salud, de marzo a diciembre de 2013. Los participantes percibían la gravedad de la enfermedad y se sentían propensos a desarrollar complicaciones de la hipertensión. Informaron que recibían tratamiento correctamente, sin embargo, los valores de la presión arterial, índice cintura - cadera e índice de masa corporal fueron altos. Es necesario que profesionales de la salud implementen estrategias de conductas de salud saludables de hipertensos en tratamiento.

Descriptores: Hipertensión; Conductas Saludables; Enfermería; Estilo de Vida.

\footnotetext{
${ }^{1}$ Universidade Estadual do Ceará. Fortaleza, CE, Brazil.

${ }^{2}$ Faculdade Metropolitana de Fortaleza. Fortaleza, CE, Brazil.

Corresponding author: Ariane Alves Barros

Rua C, 85, Loteamento Expedicionários I, Itaperi. CEP: 60745-540. Fortaleza, CE, Brazil. E-mail: arianealvesbarros@hotmail.com
} 


\section{Introduction}

Social, cultural and political changes that take place in society affect directly the population's health status. After the 1960s, an increase in life expectancy and changes in the epidemiological profile were identified, with a reduction of infectious diseases and intensification of non-communicable chronic diseases responsible for about $63 \%$ of global deaths in $2008^{(1)}$.

Among the infectious diseases, the systemic hypertension is highlighted because of its relation to the onset of complications such as coronary artery disease, renal failure, stroke, heart failure, among others. This disease is defined as a multifactorial clinical condition characterized by high and sustained blood pressure levels ${ }^{(2)}$.

The frequency of prior diagnosis of hypertension in the Brazilian population has a prevalence of $22.7 \%^{(3)}$. This is worrying and it alerts health professionals, especially those in the primary health care network, to investigate risks for the onset of systemic hypertension, assisting individuals in the adoption of healthy behaviors for the prevention of this disease.

Each person affected by hypertension is unique and adopts a lifestyle consistent with their beliefs, perceptions and knowledge ${ }^{(4)}$. Therefore, it is imperative that nurses know how to recognize them, providing care guided by their needs, in order to facilitate adherence to the treatment and empower individuals for self-care. In this context, the Health Belief Model can be used by health professionals as a theoretical framework to explain human behavior related to the health-disease process. This model helps understand changes and maintain patients' behaviors, enabling the investigation of the benefits and barriers of the adoption of preventive measures ${ }^{(5)}$.

The Health Belief Model is divided into four areas: perception of vulnerability or susceptibility, which is the subjective perception of personal risk of contracting a disease; severity, when the individual associates the disease with serious consequences; benefits, in which the subject believes in the effectiveness of the action and correct use of medicines, and its positive consequences; and perceived barriers, which are the difficulties for not following the recommended treatment ${ }^{(6-7)}$.

Given the above, one can see that systemic hypertension worries health professionals and people affected by it due to the possibility of complications, physical and psychological sequelae, or even death of hypertensive patients.

In this context, it was questioned: What are the health behaviors developed by hypertensive patients assisted in primary health care? What are the beliefs related to the disease's severity and susceptibility, and the perceived benefits and barriers? Thus, it was aimed to know the lifestyle of hypertensive patients, focusing on their health behaviors in light of the health belief model.

\section{Method}

Cross-sectional study, conducted with a sample of 133 patients registered in the Clinical Management System for Hypertension and Diabetes Mellitus in Primary Care, and assisted in five health facilities selected by a simple raffle in Fortaleza, Brazil. It was calculated from the formula developed for finite studies, with estimated average prevalence of hypertension in adults of $20 \%$ confidence level of $95 \%$ and a sampling error of $5 \%$.

The individuals over 18 years old, who had been accompanied at the clinic for at least one year, were included. Those who reported having diabetes mellitus or other self-reported chronic disease were excluded.

Data were collected from March to December 2013 with the help of a structured recorded interview, whose instrument was elaborated according to the Health Belief Model. The interview was divided into four parts: information about socioeconomic characteristics, data related to physical examination and treatment, identification of health behaviors and 
aspects related to the Health Belief Model.

For this study, one had as variables of interest: gender, age, occupation, marital status, education, blood pressure, weight, height, waist and hip circumference, diet, time of hypertension diagnosis and treatment time.

Blood pressure, weight and height were measured in the health units by trained professional and registered on a follow-up card, used by health professionals during consultations. These data were used as variables in the study.

The measurement of waist and hip of the patients was performed by the researchers through an inelastic tape, with divisions of $0.5 \mathrm{~cm}$, in the moment they were in the screening room. To measure their waist circumference, participants were standing upright with relaxed abdomen, legs parallel and slightly apart, with the region of waist naked, and the measurement was made in the pre-inspiring moment, with the measuring tape directly on the patient's skin between the bottom edge of the last rib and the hip bone (iliac crest) ${ }^{(8)}$.

And the hip circumference was measured under a piece of thin clothes, with the participant standing erect with arms away from the body and feet together, with the tape allocated around the hip, on the area of larger diameter, without compressing the skin ${ }^{(9)}$.

Concerning the participants' diet, information was obtained from questions that made the instrument of data collection, thus being characterized as selfinformation. The diet was classified as low sodium and low fat according to the responses of patients who claimed not having a diet high in salt and lipids.

People were invited and informed about the purpose of the study, how their participation would be, the benefits and possible risks. Those who accepted the invitation, were given the Informed Consent Form and their permission was required through their signature $^{(10)}$.

The study was approved by the Research Ethics Committee of the Universidade Estadual do Ceará
[State University of Ceará], according to Protocol number 177,060.

\section{Results}

The analysis of the health behaviors of hypertensive patients shows the need to know their socioeconomic and clinical characteristics, as shown in Tables 1 and 2.

Table 1 - Description of sociodemographic characteristics of 133 hypertensive patients of the sample

\begin{tabular}{|c|c|}
\hline Variables & n (\%) \\
\hline \multicolumn{2}{|l|}{ Age (years) } \\
\hline $18-30$ & $2(1,5)$ \\
\hline $31-45$ & $12(9.0)$ \\
\hline $46-60$ & $61(45.9)$ \\
\hline$>60$ & $58(43.6)$ \\
\hline \multicolumn{2}{|l|}{ Sex } \\
\hline Male & $19(14.3)$ \\
\hline Female & $114(85.7)$ \\
\hline \multicolumn{2}{|l|}{ Occupation } \\
\hline Active worker & $19(14.3)$ \\
\hline Unemployed / Self Employed & $92(69.2)$ \\
\hline Retired / Pensioner & $22(16.5)$ \\
\hline \multicolumn{2}{|l|}{ Marital status } \\
\hline Married & $69(51.9)$ \\
\hline Not married & $64(48.1)$ \\
\hline \multicolumn{2}{|l|}{ Schooling (years) } \\
\hline No schooling & $10(7.5)$ \\
\hline $1-6$ & 53 (39.9) \\
\hline $7-9$ & $41(30.8)$ \\
\hline $10-12$ & $23(17.3)$ \\
\hline$>12$ & $6(4.5)$ \\
\hline
\end{tabular}

Patients in the study were concentrated in the age group of adults and seniors, with 56.4 and $43.6 \%$, respectively, with an average of 59.70 years old, standard deviation of 11.12 and a median of 58.5 years old. One also identified a predominance of females $(85.7 \%)$, married $(51.9 \%)$ and retired/unemployed $(85.7 \%)$. In the study, patients with no education $(7.5 \%)$ were identified, and the highest percentage of the sample had up to nine years of study. 
Table 2 - Description of the clinical characteristics of 133 hypertensive patients

\begin{tabular}{lc}
\hline Variables & $\mathbf{n}(\mathbf{\%})$ \\
\hline Time of diagnosis (years) & \\
$0-5$ & $55(41.4)$ \\
$5-10$ & $32(24.0)$ \\
$>10$ & $46(34.6)$ \\
Treatment time (years) & \\
$0-5$ & $55(41.4)$ \\
$5-10$ & $35(26.3)$ \\
$>10$ & $43(32.3)$ \\
Systolic Blood Pressure (mmHg & \\
$<130$ & $38(28.6)$ \\
$131-139$ & $33(24.8)$ \\
$140-159$ & $35(26.3)$ \\
$160-179$ & $19(14.3)$ \\
$\geq 180$ & $8(6.0)$ \\
Diastolic Blood Pressure (mmHg) & \\
$<85$ & $75(56.4)$ \\
$86-89$ & $5(3.8)$ \\
$90-99$ & $30(22.6)$ \\
$100-109$ & $12(9.0)$ \\
$\geq 110$ & $11(8.3)$ \\
Waist-hip ratio (n = 108) & \\
$<1.0$ (men) and $<0.8$ in women & $18(13.5)$ \\
$\geq 1$ (men) and $\geq 0.8($ women) & $90(67.5)$ \\
Body Mass Index $\left(\right.$ Kg $\left./ \mathrm{m}^{2}\right)$ & \\
$18.5-24.9$ & $36(27.1)$ \\
$25.0-29.9$ & $42(31.6)$ \\
$\geq 30$ & $55(41.3)$ \\
\hline & \\
& \\
&
\end{tabular}

Most patients had less than five years of diagnosis (41.4\%), with an average of 9.35 years and a standard deviation of 7.93 years. This time is consistent with the treatment time, ie, $41.4 \%$ had treatment for less than five years, demonstrating that hypertensive patients started drug treatment soon after the discovery of the disease. Out of the respondents, $23.30 \%$ of the sample reported having been hospitalized as a result of hypertension, the main reason was blood pressure peaks.

Systolic blood pressure was above the normal range in $46.6 \%$ of participants and diastolic blood pressure remained in the normal level or threshold in $60.2 \%$ of patients. These percentages were identified by individual classification of systolic and diastolic pressures, showing a predominance of very common isolated systolic hypertension in the elderly.

It was also identified high percentages of subjects with waist-hip ratio higher than expected $(67.5 \%)$, with body mass index predominating between overweight (31.6\%) and obesity (41.4\%).

Regarding their lifestyle, it was found out that the majority had health behaviors related to nonpharmacological treatment of hypertension, in which $70.6 \%$ reported eating fat diet, $83.4 \%$ reported low sodium diet, $83.4 \%$ did not consume alcohol and $91.7 \%$ were non-smokers. In contrast, only $34.5 \%$ of the patients underwent a type of physical activity such as walking and aerobics.

By analyzing the behaviors of patients in light of the Health Belief Model, one identified divergent discourses among patients when they responded to the questions related to the susceptibility and severity of the disease: $69.2 \%$ felt susceptible, fearing complications of the disease, $94.7 \%$ believed they lived well with the disease and $89.5 \%$ showed concern to their keep blood pressure under control. Among the complications that patients felt more susceptible to, stood out acute myocardial infarction (91.7\%), stroke (93.2\%), vision problems $(72.2 \%)$ and kidney problems (64, 7\%), due to the disabling sequelae.

The disease's severity was reported by $96.2 \%$ and the possibility of bringing the patient to death was perceived by $97.0 \%$ of the patients. Participants also believed that hypertension harms individuals, whether in their social activities (20.3\%), family life $(22.6 \%)$, at work $(27.8 \%)$ or financial situation (24.1\%). This condition led them to move away from friends to avoid intake of alcoholic beverages and/ or smoking, and others got away from work to avoid fatigue and stress, important allies in the elevation of blood pressure.

Among the perceived benefits, the highlights were the orientations given by healthcare professionals during the consultation, which 100\% of patients reported to like. The taking of medications was reported as a priority by $94.7 \%$ of participants; 91.7\% reported having all medications, even with financial difficulties, even when there were no drugs in the pharmacy of basic health units and even in popular 
drugstores, so that they had to get the medicines in private pharmacies with a higher cost .

When considering family support to the patient's adherence to health behaviors, $44.3 \%$ of the respondents reported that their families did not always support their treatment, making it difficult, especially in the food question. Other barriers perceived by them to adopt health behaviors were: not doing physical activities (65.4\%) and not being able to stop drinking (16.5\%) and smoking (8.2\%).

\section{Discussion}

This study highlights the prevalence of hypertension among older people, since there is a direct and linear relationship between the increase in blood pressure with age ${ }^{(2)}$. Another consistent finding was the predominance of female participants, pointing to the fact that women have better attendance to health services. A study conducted in Fortaleza-Ceará presents a percentage of women ( $\geq 18$ years old) who reported medical diagnosis of hypertension of $20 \%$ and men of $14 \%{ }^{(3)}$.

Women attend more assiduously health services, recognizing the changes that occur in their bodies, identifying each new sign that appears, then, they know more quickly how to diagnose their illnesses. However, health professionals should pay attention to the male population for which they are responsible, and health services should reach them, even though actions to do so require more dedication.

In this study, a minority of the participants declared themselves as active workers corroborating with another research that showed that these patients probably come from families that do not have a good quality of life due to low incomes, observing thus a higher frequency of hypertension in low economic classes $^{(11)}$. Regarding marital status, the percentage between married and unmarried remained close, however, it is known that the family plays an important role in providing and maintaining the patient's wellbeing, supervising and assisting in the completion of the treatment $\mathrm{t}^{(12)}$.

Low schooling affects people's health, which may hinder the understanding of information and consequently hinder the adherence to the treatment, increasing their exposure to risk factors ${ }^{(13)}$. One identified low education in this study because patients had a maximum of nine years of study.

It was found that $65.4 \%$ of the patients had diagnosis time of hypertension of less than 10 years, getting closer to the findings of another study, in which $60.3 \%$ of the sample had up to 10 years of diagnosis ${ }^{(14)}$. The time that the patient has of hypertension diagnosis may influence the development of complications, because the longer they have the disease, the higher the chances to develop lesions in target organs such as the heart, the brain and kidneys.

The time of treatment of systemic hypertension was consistent with the time of discovery of the disease, in which only three patients reported taking some time to start the treatment after the discovery of the disease. This fact allows us to verify patient's adherence to the pharmacological treatment.

The process of adherence to the treatment of chronic diseases is complex and it usually requires a sudden adaptation to a new lifestyle and the adoption of healthy behaviors. This process is permeated by the individual's family, social, economic and cultural context. Therefore, dialogue between health professionals and patients is important, aiming to understand this subject in its entirety ${ }^{(15)}$.

The study participants were also interested in maintaining a low sodium and low fat diet. Excess sodium in a diet is a risk factor and it can raise blood pressure, low-fat diet contributes to the maintenance of body weight, preventing obesity. Daily intake of sodium should be about $100 \mathrm{mEq} /$ day, which is equivalent to six grams of salt or a teaspoon. Concerning weight control, for every $10 \mathrm{~kg}$ of weight reduced, there is a reduction from 5 to $20 \mathrm{mmHg}$ in systolic blood pressure ${ }^{(2,16)}$.

However, body mass index isolated is not able to detect systemic changes that come from overweight. 
Therefore, it is also used the measure of waist/hip ratio, as a way to supplement the data obtained. And in this study it was identified a high percentage of subjects with altered waist/hip ratio (67.5\%).

The body mass index and waist/hip ratio are indicators of fat, both body and abdominal, and are strongly associated with systemic hypertension. This fact was also confirmed in a study conducted with 2,143 elderly in São Paulo, where it was found that excess fat, regardless of the anthropometric indicator used, is one of the main risk factors for arterial hypertension $^{(17)}$.

When considering the health behaviors of patients in the study, it was noticed that the discourse of patients were contradictory with the observed reality. After all, they reported that they followed the recommended diet during consultations, restricting salt and lipids, however, the body mass index and waist-hip ratio showed the opposite.

The consumption of alcohol and smoking were observed in a smaller proportion among patients in the study. Ethanol, if consumed in large amounts, can increase blood pressure and the risk of cardiovascular morbidity and mortality. The dose of ethanol to be consumed by men should not exceed $30 \mathrm{~g}$ a day and by women this value should not exceed $15 \mathrm{~g}$ a day ${ }^{(2)}$.

The practice of physical exercise, in turn, had low adherence among the study participants. Thus, one highlights the need for educational activities that encourage this practice. The practice of regular exercise can reduce morbidity and mortality, lowering blood pressure and associated risk factors ${ }^{(18)}$.

A fact mentioned by patients, mostly in relation to diet, was the difficulty to perform the recommended dietary prescription, because of family and social eating habits. Then, family and social support contributes to a successful treatment, which will make the restrictions only one stage to be surpassed. The family is an indispensable point for proper completion of the treatment, providing emotional support to the patient ${ }^{(19)}$.

The survey participants reported they are able to keep blood pressure under control, besides the importance of following the treatment correctly, regardless of the number of medicines. They also believed that the guidance provided by the health professionals should always be followed to prevent complications and improve their health.

Knowledge about the disease's severity and the perceived susceptibility may motivate individuals to act, and if they are not able to generate such an act, there must be greater incentive to change, after all, these two factors together will make patients realize their proximity to other health problems resulting from the underlying disease, causing them to act in a more appropriate way ${ }^{(20)}$.

The perceived benefit is also essential for patients. It is in this moment that there is a predominance of beliefs about the importance of health treatment and trust in the professionals ${ }^{(7)}$. However, some patients fail to observe the benefits clearly, especially when they start to affect their social and family life.

The barriers are perceived and interpreted in a particular way by each patient, depending on how they are present in their lives. However, one must consider that the personal difficulties, such as eliminating a risky lifestyle, controlling their diet and taking the indicated medicine require high investment by patients ${ }^{(7)}$.

\section{Conclusion}

It can be seen by this study that hypertensive patients' lifestyles are able to directly influence blood pressure values. It is also responsible for defining patients' health behaviors, indicating therefore their quality of life.

One found as a relevant result and related to lifestyle, the concern in performing a healthy diet with low fat and low sodium, demonstrating that participants have knowledge about the disease and their susceptibility to complications.

The study also showed how the Health Belief 
Model contributes to the adoption of a healthier lifestyle, with a focus on adherence to the treatment and on the identification of issues that should be worked in the nurse-patient relationship.

After all, a more effective nursing care can be obtained when beliefs about susceptibility and severity of the disease and the benefits and barriers to care are considered and direct patients' approach, assisting in the identification of their lifestyle and improving their quality of life.

\section{Acknowledgements}

We appreciate the support of the Conselho Nacional de Desenvolvimento Científico e Tecnológico [National Council for Scientific and Technological Development].

\section{Collaborations}

Barros AA and Guedes MVC contributed to the design, field data collection, analysis, interpretation of data and drafting of the article. Moura DJM and Menezes LCG contributed to the analysis and interpretation of the article. Barros AA, Guedes MVC, Aguiar LL and Xavier GA contributed to the design and final approval of the version to be published.

\section{References}

1. World Health Organization. Non communicable diseases country profiles 2011. Geneva: WHO; 2011.

2. Sociedade Brasileira de Cardiologia. Sociedade Brasileira de Hipertensão. Sociedade Brasileira de Nefrologia. VI Diretrizes Brasileiras de Hipertensão. Arq Bras Cardiol. 2010; 95(supl.1):151.

3. Ministério da Saúde (BR). Secretaria de Vigilância em Saúde, Secretaria de Gestão Estratégica e Participativa. Vigitel Brasil 2011: vigilância de fatores de risco e proteção para doenças crônicas por inquérito telefônico. Brasília: Ministério da Saúde; 2012.
4. Moreira AKF, Santos ZMSA, Caetano JA. Aplicação do modelo de crenças em saúde na adesão do trabalhador hipertenso ao tratamento. Physis. 2009; 19(4):989-1006.

5. Cruz EDA, Pimenta FC, Hayashida M, Eidt M, Gir Er. Staphylococcus aureus detection in the mouth of housekeepers. Rev Latino-Am Enfermagem. 2011; 19(1):90-6.

6. Santos ACL, Gubert FA, Vieira NFC, Pinheiro PNC, Barbosa SM. Modelo de crenças em saúde e vulnerabilidade ao HIV: percepções de adolescentes em Fortaleza-CE. Rev Eletr Enf. [periódico na Internet]. 2010; 12(4):705-10. Disponível em: http://www.fen.ufg.br/fen revista/v12/n4/pdf/v12n4a16.pdf.

7. Dela Coleta MF. Crenças sobre comportamento de saúde e adesão à prevenção e ao controle de doenças cardiovasculares. Mudanças Psicol Saúde. 2010; 18(1-2):69-78.

8. Ministério da Saúde (BR). Secretaria de Atenção à Saúde. Departamento de Atenção Básica. Orientações para a coleta e análise de dados antropométricos em serviços de saúde: Norma Técnica do Sistema de Vigilância Alimentar e Nutricional. Brasília: Ministério da Saúde; 2011.

9. Ministério da Saúde (BR). Vigilância Alimentar e Nutricional: orientações básicas para a coleta, processamento, análise de dados e informação em serviços de saúde. Brasília: Ministério da Saúde; 2004.

10. Ministério da Saúde (BR). CNE/CONEP. Resolução no 466/2012. Conselho Nacional de Saúde de 12 de dezembro de 2012 [Internet] 2012 [citado 2013 out. 10]. Disponível em: http://conselho. saude.gov.br/resolucoes/2012/Reso466.pdf

11. Ramos FFA, Maia JA. Tratamento da hipertensão arterial entre usuários idosos assistidos pela enfermagem numa unidade básica de saúde da família. Rev Bras Educ Saúde. 2013; 3(2):9-16.

12. Oliveira RG, Frota NM, Martins ABT, Silva CJA, Santos ZMSA. Accession of user interface and treatment hypertensive relationship with the Family. Rev Enferm UFPI. 2013; 2(4):42-9.

13. Berlezi EM, Schineider RH. Análise de Risco Cardiovascular em Hipertensos Adscritos a uma Unidade de Estratégia de Saúde da Família. Rev Contexto Saúde. 2009; 9(17):45-52. 
14. Alves MCB, Brito FN, Lima LM, Matos VC, Sousa JCS, Leite DKM et al. A qualidade de vida de pacientes hipertensos em uma estratégia saúde da família, Ananindeua-Pará. Rev Eletr Gestão Saúde [periódico na Internet]. 2013; 4(1):165971. Disponível em: http://gestaoesaude.unb.br/ index.php/gestaoesaude/article/view/320.

15. Cavalari E, Nogueira MS, Fava SMCL, Cesarino CB, Martin JFV. Adesão ao tratamento: estudo entre portadores de hipertensão arterial em seguimento ambulatorial. Rev Enferm UERJ. 2012; 20(1):6772.

16. Ribeiro AJP, Fachineto S, Pedrozo SC, Trentin, AP, Zapoani C. Prevalência de sobrepeso e obesidade em escolares com idade de 7 a 17 anos, residentes nos municípios pertencentes à secretaria de desenvolvimento regional de São Miguel do Oeste/ SC. Conexões: Rev Fac Educ Física UNICAMP. 2013; 11(1):57-73.
17. Munaretti DB, Barbosa AR, Marucci MFN, Lebrão ML. Hipertensão arterial referida e indicadores antropométricos de gordura em idosos. Rev Assoc Med Bras. 2011; 57(1):25-30.

18. Nogueira IC, Santos ZMSA, Mont'Alverne DGB, Martins ABT, Magalhães CBA. Efeitos do exercício físico no controle da hipertensão arterial em idosos: uma revisão sistemática. Rev Bras Gerontol. 2012; 15(3):587-601.

19. Alencar DC, Alencar AMPG. O papel da família na adaptação do adolescente diabético. Rev Rene. 2009; 10(1):19-28.

20. Santos ZMSA, Caetano JÁ, Moreira FGA. Atuação dos pais na prevenção da hipertensão arterialuma tecnologia educativa em saúde. Ciênc Saúde Coletiva. 2011; 16(11):4385-94. 